\title{
Ekologická etika - na pomezí etikety a revoluční ideologie
}

\section{Jana Dlouhá}

Envigogika 2007/II/1 - Recenzované články/ Reviewed Papers

Publikováno/Published 16. 04. 2007

DOI: http://dx.doi.org/10.14712/18023061.13

\begin{abstract}
Abstrakt:
Stručný rozbor východisek a směrů ekologicko-etického myšlení je konfrontován s aktuálními vzdělávacími požadavky - zdůrazněna jsou rizika povrchního uvažování $\checkmark$ kontextu současných problémů a modelů jednání navrhovaných pro krizové situace, jež vedou ke konstrukci nutných „vzorců chování". Tradiční filozofie morálky však nabízí přinejmenším inspiraci také pro hlubší úvahy o takovém způsobu existence, jež by byl v souladu s mimolidským světem.
\end{abstract}

\section{Klíčová slova:}

Filozofie etiky, holizmus, směry ekologické etiky, důsledky pro vzdělání

\begin{abstract}
:
A brief discussion of foundations and directions of the ecological-ethical thought is confronted with the present-day requirements on education, highlighting the risks of superficial thought in the context of the present problems and behaviour models suggested for crises, which lead to constructing the necessary 'behaviour patterns'. Conventional philosophy of morality, however, offers inspiration at least for a more profound reflection on such a manner of existence that would be in harmony with the non-human world.
\end{abstract}

\section{Key words:} education

Philosophy of ethics, holism, directions in ecological ethics, implications for 


\section{Úvod}

Pouhé informace o zhoršujícím se stavu životního prostředí nebo i vědecké prognózy samotné nemohou přinést skutečnou a pozitivní změnu smýšlení a tolik žádanou reorientaci společnosti ${ }^{1}$. Samotné ohrožení nemá schopnost probudit zájem o společné dobro, at' již je jím myšlen trvající blahobyt společnosti či nárok na přežití všech živých tvorů. $\mathrm{V}$ takových situacích se naopak lidský jedinec i jeho společenství mohou chovat značně nepředvídatelně, jde jim totiž o jediné: zajistit okamžité výhody, ochránit především sebe a svou rodinu! Podobné prípady popisuje Marc Pratarelli ve své knize Niche Bandits: lidé, kteří dobře znají mořskou faunu a vědí o nutnosti její ochrany, přesto vzácné druhy nelítostně rabují. Jestliže by tak nečinili, našel a zlikvidoval by je jistě někdo jiný... (Pratarelli, 2003). Jde o chování přirozené, popsané i v teorii her jako tzv. Vězňovo dilema - ačkoli by se $v$ daném prípadě spolupráce dlouhodobě možná vyplatila, momentální „zrada" přináší vyšší okamžitý zisk (Uhliř, 2006). Vyčerpání přírodních zdrojü tak může být nevratné již ve velmi blízké budoucnosti: mořský svět, jak bylo výše uvedeno, je skutečně vážně ohrožen, druhy fauny co do množství i rozmanitosti postupně mizí, jsou bezmocné nejen proti lidské hrabivosti vystupňované poklesem úlovku a tedy jeho zvyšující se cenou, ale mají stále menší šanci především proti pokrokové technice rybolovu.

$\checkmark$ nebezpečné situaci, které vážné narušení prostředí s sebou nese, nepředstavují přirozené lidské reflexy vhodný záchranný mechanismus. Ani tzv. "krizové scénáře" však nemusí být spolehlivou variantou - např́klad vážně promýšlená strategie pro situace, kdy je potřeba ochránit věc veřejného zájmu před krátkozrakým a chamtivým vlastnickým postojem, vychází z tzv. etiky záchranného člunu. Nemúžeme se prý spolehnout na svědomí: i lidé dobré vůle často nedovedou myslet dlouhodobě, a proto potřebujeme donucovací mechanismy určitého druhu. $K$ vyhraněné formě této "etiky" pak patří poznání, že je nás př́liš mnoho, že se dělíme o zdroje - a je proto nutné ochránit si své výsady, kulturní hodnoty a úroveň spotřeby proti těm, kteří jsou na "vývojově nižší úrovni" (Kohák, 1998).

Spoléhat se na „přirozené", naléhavostí situace vynucené, jednání či nedokonalé, historicky a politicky poplatné společenské mechanismy se nevyplatí. Takové predání kompetencí jakési "vyšší instanci", víra v "systémové řešeni" zajištěné neomylnými silami př́rody či nedotknutelným právním, institucionálně zabezpečeným řádem, zbavuje odpovědnosti. Vkládá ji však na bedra, jež ji neumějí, anebo ne vždy chtějí nést. $\mathrm{K}$ nápravě daného stavu nemůže přispět systém, který $\mathrm{s}$ dobrou vưlí nepočítá a pouze vyrovnává individuální sobecké zájmy či kompenzuje prostou pohodlnost - svět, a tedy i naše právní a politické prostředí, vždy bude takový, jací jsme my sami.

Ekologická či environmentální výchova je pokusem o zvrat této situace. Pečuje o lidskou bytost $v$ období jejího vývoje, a $k$ tomuto principu péče, který se týká světa lidského i mimolidského, pak poukazuje jako k principu univerzálnímu. Vede $k$ zájmu o život $v$ jeho různých podobách, a pěstuje schopnost jej účinně bránit. Není však zcela Ihostejné, jakým způsobem tak činí. Pokud například je kladen př́liš velký důraz na pouhé předávání znalostí o životním prostředí, může to vést jen $\mathrm{k}$ frustraci a apatii dětí a malé motivaci $\mathrm{k}$ odpovědnému jednání. Obavy a lhostejnost studentů pak musí být pracně napravovány - může $\mathrm{k}$ tomu přispět např́klad rozvoj tzv. akčních kompetencí v environmentální oblasti, jak poukazuje Jan Činčera v minulém čísle Envigogiky (Činčera,

\footnotetext{
1 Závěr mezinárodního hodnocení ekosystémů (UNDP, UNEP, World Bank and WRI, 2000): „Pokud budeme pokračovat $v$ současných vzorcích spotřeby, budeme téměř s určitostí čelit snížené schopnosti ekosystémů poskytovat široké spektrum služeb - počínaje pitnou vodou přes stabilní klima, dřevo, plodiny a vlákna až po stanoviště volně žijících rostlin a živočichů."
} 
2006). Složitý výraz zahrnuje jednoduchou zásadu: posilovat schopnost samostatně a odpovědně jednat v zájmu toho, co dítě-člověk pokládá za obecně dobré.

Dobro, co to vůbec je a jak jej Ize dosáhnout, to je jedno z témat etiky. Tento pojem se vztahuje $\mathrm{k}$ praktické životní angažovanosti, mimo tuto oblast je pouhým (často vysmívaným) konstruktem. K pochopení či spíše uchopení toho, co je dobré, se propracováváme rozumnými úvahami, na nichž Ize založit životní rozhodnutí a praktické jednání. Rozvažování tohoto druhu má pro vzdělání stejný význam jako úvahy teoretické (či technicky aplikované), jejich metoda je však zcela odlišná. Teorie rozpracovávané vědou, jejich závěry, mají platnost obecnou; vědecké principy nezávisí na kontextu a produkty vědou založené techniky slouží bez ohledu na účel. V této oblasti nelze hledat odpověd’ na otázku „Proč, jaká jsou východiska snažení?" ani „K čemu, jaký to má smysl?" Jednání, které by bylo založeno jen vědecky a vycházelo pouze z ověřených fakt a informací, nemusí mít, a také nemá morální důvod ani cíl - je z tohoto pohledu naprosto irelevantní. Etika je tak svébytnou oblastí úvah praktického rozumu, kterou je nutné si uvědomovat a ctít samostatně (mimo okruh myšlení teoretického, hermeneutického výkladu skutečnosti či prosté reflexe), a to s ohledem na účast ve světovém dění. Praktické úvahy znamenají nejen vždy nové, konkrétní situaci odpovídající promýšlení etických argumentů, ale také potom jejich využití v souladu s vnitřním přesvědčením, jež je stále zajišt́ováno rozvahou vedoucí k výběru "správných", tedy obecným principưm i konkrétní situaci odpovídajícím, argumentů.

\section{Etika ve škole}

Úvodem př́klad: v Národním kurikulu pro Anglii, což je dokument zahrnující všechny výukové aj. zkušenosti, je etika vưdčím principem, od nějž se další cíle druhotně odvozují. Již ve své první kapitole Základní hodnoty a cíle vytyčuje tyto zásady:

„Vzdělání ovlivňuje a odráží společenské hodnoty, a přispívá k tvorbě společnosti, jakou bychom chtěli mít. [...] Nejdưležitější je přesvědčení, že vzdělání, at' již doma či ve škole, je cestou k duchovnímu, morálnímu, sociálnímu, kulturnímu, fyzickému a mentálnímu rozvoji, a tím i dobrému životu (well-being) jednotlivce. [...] Cílem vzdělání je pak efektivně tyto hodnoty prosazovat..." (QCA, 2007).

Český Rámcový vzdělávací program deklaruje „výrazně formativní funkce" a dále je rozvíjí například ve smyslu kompetencí sociálních a personálních, jež mají posilovat sebevědomí dětí na základě poznání a pochopení vlastní osoby, a pěstovat povědomí o základních mravních hodnotách $v$ rodině i ve společnosti. Prưrezové téma environmentální výchova má přispívat $\mathrm{k}$ rozvoji osobnosti žáka $v$ oblasti postojů a hodnot například tím, že napomáhá vnímání života jako nejvyšší hodnoty či vede k odpovědnosti ve vztahu $k$ biosféře, $k$ ochraně přírody a přírodních zdrojů (VúP, 2006). V praktické rovině se však etický rámec poněkud vytrácí - vzdělávací oblasti či prưřezová témata jsou vedena snahami o sice žádoucí, někdy však přiliš technicky pojaté dílčí cíle a změny.

Koncepční zaměření na určité, společností sdílené, hodnoty teprve z osnov vytváří celek, který není pouhým souborem navzájem nesouvisejících částí. Smysluplným celkem se učivo stává s ohledem na to, o co při učení vůbec jde - tedy v souvislostech osobního a sociálního rozvoje (Delors, 1997, s. 49-58). Holistický pohled, z něhož se odvozují dílčí principy poznávací, se utváří vzhledem k účasti ve světovém dění a smyslu této osobní angažovanosti (př́kladem je synkrisis - metoda poznání popisovaná J. A. Komenským. Nevychází ze spekulativního pohledu na skutečnost, a přesto poskytuje vhled do jejího jádra; je založena na hledání vlastní úlohy ve světě, chápe skutečnost na základě analogií; a vede k porozumění, jež je založeno na blízkosti a kontaktu, nikoli odtažitém odstupu). Praktické cíle vzdělání vždy míŕi do smysluplného světa, jež má svưj význam i pro jednotlivce, jsou stanoveny vzhledem $\mathrm{k}$ jeho př́štímu životnímu úkolu a poslání, a $v$ jejich základu je tak př́tomna představa o tom, co je pro všechny "dobré". Vzdělávací cíle se tedy ustavují s ohledem na ten rozměr skutečnosti, který přesahuje bezprostřední danost a směřuje do budoucnosti - a právě v této dimenzi je pak třeba hledat základní "pojivo", 
jež váže dohromady stavební kameny poznání. Na tento poukaz k celkovému smyslu spoléhá celá oblast poznávací, nebot' „...je úkolem vševědy ukázat člověku smysl veškerenstva. A toto naplnění člověka smyslem veškerenstva, toto odpovídání mezi člověkem a jsoucnem $v$ celku bude znamenat, že vůle člověka bude ovládána rozumovým pochopením toho, co je člověku bytostné a k čemu je sám určen." (Komenský, 1948). Bez toho by námi pochopené struktury logických souvislostí neměly nic společného se životem samým a nebylo by je možné ani v praxi použít; na takto získané pravdy by nebylo možné se (životně) spolehnout, neumožnily by účast na životě - o tento podíl i ve vzdělání jde.

Dílčí prvky a součásti osnov či vzdělávacích programů tak mají alespoň implicitní vztah k celkovému záměru či smyslu - jinak by došlo v konkrétních výukových situacích ke ztrátě základní orientace $v$ nepřehledném informačním terénu. Narušena může být i motivace dětí a jejich důvěra $v$ to, že se $v$ záplavě nesourodých poznatků Ize vůbec vyznat. Ač se tedy etický základ a hodnotově orientovaná východiska zdají být - díky své metafyzické povaze - filozoficky zastaralé2, pro tvorbu vzdělávacích konceptů jsou stále nepostradatelné. Vzdělávací systémy se jich nehodlají vzdát - nanejvýše jsou ochotny již vzniklé a časem se přeživší rámce re-konstruovat dle nových sociálně či environmentálně orientovaných požadavků (viz teorie kritického kurikula In: Fien, 2004).

Po překonání roztř́štěnosti poznání se volá zvláště dnes ${ }^{3}, v$ situaci, jejíž postmoderní charakteristiky neumožňují často dospět $\mathrm{k}$ jakkoli potřebným řešením. V nezúčastněném pohledu teoretického poznání se totiž rưzné přístupy ke skutečnosti stávají zcela nezávislými diskursy, jež jsou založeny na odlišných předpokladech. Nelze najít společná východiska, a vzniká mezi nimi tzv. různice, jež se projevuje zvláště v konfliktních situacích: rozpory mohou podléhat soudu (úsudku) jen dle pravidel svého žánru. Neexistují meta-pravidla a v případě, že konflikt vzniká mezi stranami, které praktikují odlišné žánry, není možné vynést spravedlivý verdikt. Jedná se o různici („différend") doprovázenou nespravedlností ("tort"): jeden z žánrů získává výsadní postavení a brání jiným žánrům, aby uplatňovaly své nároky (Keulartz, 1998). Tedy by nebyla možná ani žádná praktická řešení - a to platí zvláště pro popis vztahu ekologie a ekonomie, trh - příroda. Ekologický a ekonomický diskurs nejsou $v$ tomto pohledu protiklady, ale různice. Neexistuje společný bod či pole, na kterém by se mohly střetnout. Mezi ekologickými mysliteli a ekonomy z "fundamentálních", „fyzikálních" důvodů nemůže dojít k dialogu, protože ekonomická věda nepočítá $s$ prírodními změnami $v$ delších časových horizontech, kdežto důsledky narušení větších ekosystémů se většinou projevují za dvacet let a více. Ekologický a ekonomický pohled na svět se navzájem vylučují a můžeme pouze volit mezi jedním z nich. Nejde však o nich diskutovat, př́t se, rozhodovat, který je pravdivější. Jejich pravdy se totiž navzájem míjí (Binka, 2005).

Takové bezvýchodné, neřešitelné situace by ve školním vzdělání byly rezignací na jeho základní úlohu. Má tedy etika, jako praktický zpưsob uvažování o možnostech podílet se na stavu světa, pro tvorbu vzdělávacích konceptů zásadní význam (nemá být tedy jen souborem pravidel slušného chování). Hodnotové rámce mají ve škole primární postavení, a samotné vědění je až druhotným či odvozeným materiálem pro realizaci kurikulárních cílů - což také odráží zásadní zkušenost, že i život je prvotně orientovaný mezi póly dobra a zla, pravdy a nepravdy. V tomto poli je pak vedeno praktické úsilí, jež je určitým

2 Metafyzická východiska - srovnej např. Průková, M. Myšlenkové podhoubí a východiska modernismu. Paideia, Číslo/Ročník/Rok: 1/II/2005. ISSN 1214-8725. [2007-01-22] Dostupné z www: $<$ http://userweb.pedf.cuni.cz/ paideia/index.php?pg=3\&id=18\&lbs $=4>$.

${ }_{3}$ Viz např.: „Kurikulární reforma českého školství mění základní cíle vzdělávání a nahrazuje tradiční pojetí zaměřené na pamětové osvojování velkého množství poznatkư $v$ hotové podobě. ... Potřebu integrace už zavedených předmětů mají v rámcových vzdělávacích programech naplňovat tzv. prưrezová témata." HUČíNOVÁ, L.: Integrace v rámcových vzdělávacích programech? Citováno [200601-12] Dostupné z www:<http://www.vuppraha.cz/index.php?op=sections\&sid=184> 
způsobem zaměřeno a soustřed'uje životní energii k jistému (byt́ nikoli dogmaticky stanovenému) cíli.

V následujících odstavcích se pokusím vymezit, co je myšleno hodnotami, celkovým smyslem a praktickým rozvažováním. Položím si otázku, proč tyto kategorie rozmýšlet samostatně a jak, z jakého pohledu k nim přistupovat. Budu předpokládat, že pro chápání místa člověka ve světovém dění a utváření jeho poctivého vztahu ke skutečnosti mohou být poznatky a vědomosti vycházející pouze $z$ teoretického prístupu ${ }^{4}$, $a$ tedy nezúčastněného postoje ${ }^{5}$, zcela irelevantní. To potvrzuje zkušenost, že sebedưmyslnější stavba vědomostí nepřivede k platné účasti; naopak, čím více je život obklopen a naplněn "objektivními informacemi", tím spíše se otevírají př́ležitosti pro životní dezorientaci. $\checkmark$ př́padech, kdy jde o vztah (spolu)účasti, mohou a mají být životní situace popisovány metaforami poukazujícími k celkovému, hlubšímu smyslu; rozhodnutí je pak nutné činit na základě praktického rozumu.

Během těchto úvah je nutné si stále připomínat, že $v$ mnoha ohledech Ize navázat na kulturu, ve které (pořád ještě) vyrůstáme. Hodnoty, i když v současné době hledáme jejich společného jmenovatele pro multikulturní svět, budou vždy mít platnost individuální či kulturně podmíněnou. Především $v$ oblasti ekologické etiky je proto dobré si vzpomenout, co utvářelo podobu naší civilizace. Mnohé ekologické směry totiž implicitně zahrnují přesvědčení, že právě naše kultura se neosvědčila, že se nezodpovědně odcizila přirozenému světu, vydala se napospas technice a jejím samovolným a zničujícím mechanismům. Je však možné, že to my jsme se neosvědčili, nedostáli jsme své

\footnotetext{
${ }^{4} \mathrm{~K}$ teoretickému přístupu viz např. (Stehura, 2006): „Předpokládejme tedy, že rozumové stránky jsou

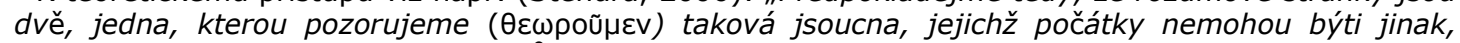

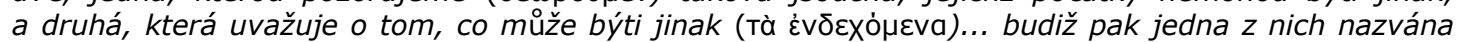

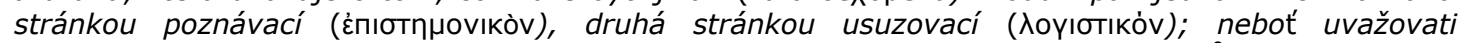

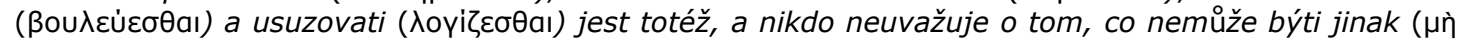

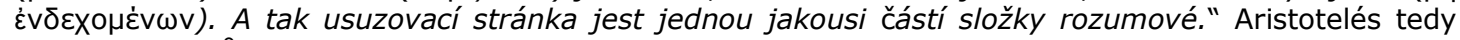
rozlišuje dvě různé schopnosti či části rozumné duše. Ukazuje, že se každá z nich obrací ke svému zvláštnímu předmětu, a tím vlastně teprve jasně ustanovuje jejich různost. Kdyby totiž neměla každá svưj zvláštní předmět, nejednalo by se patrně o dvě rưzné části. Poznávací část racionální duše je

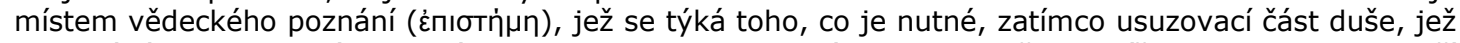
se zabývá kontingentním, je místem rozumnosti. Nahodilé jsoucno totiž, jak píše Aristoteles, "netvoří předmět vědeckého zkoumání ( $\theta \varepsilon \omega \rho i a)$." Rozumnost se tedy zabývá věcmi, jež nejsou nutné, tedy takovými věcmi jež mohou být jinak, než jsou. (str. 16) Rozumnost se vztahuje na jedné straně k jednotlivinám, na druhé straně k obecninám. Aristoteles totiž ř́ká: "Rozumnost se také netýká

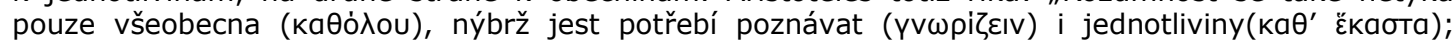
nebot' vede $\mathrm{k}$ jednání a jednání (пра̃ छı)) se týká jednotlivin. Proto také někteří lidé, kteří nemají vědění, jsou $v$ praktickém jednání i $v$ ostatních oborech zběhlejší než ti, kteří mají vědění, zvláště to

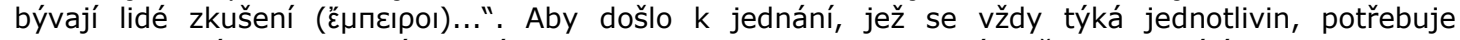
rozumnost znát jak obecné etické principy, tak i jednotliviny. A tím, že se zaobírá jednotlivinami, nebot' ty náleží do sféry nahodilosti, se odlišuje od vědeckého poznání, jež se týká obecného, a tedy nutného. Vědecké poznání není praktické, nýbrž je teoretické; nezabývá se jednotlivinami, ale obecnými zákonitostmi, a zkoumá nutné vztahy mezi obecninami, nikoli mezi jednotlivinami. (str. 17) Všimněme si zde ještě jiné distinkce než mezi racionálním a iracionálním, a to rozdílu mezi praktickým a teoretickým. Teoretické myšlení se zabývá vědeckým poznáním (દ̇nıorn்n), jeho cílem je dosažení pravdy a při jeho aktivitě je aktivní pouze rozumová složka duše. Předmětem praktického myšlení je lidské jednání, prostor kontingentní lidské činnosti a tvorba. Jednání nesměřuje pouze k dosažení pravdy, k čemuž stačí rozum, nýbrž $\mathrm{k}$ dosažení pravdy, která souhlasí se správnou žádostí. Při správné volbě kooperují mohutnosti racionální i iracionální složky duše, rozum a žádost (str. 39) Teprve interakce mezi rozumem a žádostí podle Aristotelova názoru otevírá prostor pro etické jednání. Rozum sám, uvažování samo o sobě, nemůžeme mravně hodnotit. Teoretický rozum (غ̇nıorn่un) se vztahuje ke sféře nutného, poznává nutné pravdy; leží tedy mimo oblast etiky, nebot' etika se zabývá kontingentním. Praktický rozum ( $\left.\varphi \rho \operatorname{vó}_{\eta} \sigma \sigma_{\varsigma}\right)$ má za předmět kontingentní skutečnosti, zabývá se tím co je v naší moci. (str. 64)

${ }_{5}$ Nezúčastněný teoretický postoj viz též Dlouhá, J.: Prostory účasti (s osudem světa) Envigogika 1/2007 [Citováno 2006-03-19]. Dostupné z www <http://envigogika.cuni.cz/>
} 
odpovědnosti. Základy odpovědného přístupu k přírodnímu světu zde jsou, jen je třeba na ně stále (výchovně) poukazovat.

\section{Vzdělání = vyvádění}

Význam latinského „educare" je skutečně vy-chovávat děti, podporovat je v mentálním i fyzickém růstu, přispívat $\mathrm{k}$ jejich rozvoji; ostatně bylo používáno i ve smyslu péče o zdárný rưst rostlin a zvířat. Naproti tomu „educere" znamená vy-vádění, v překladu metaforicky odkazuje na cestu vyžadující průvodce $v$ nepřehledném terénu a pomocníka při dosahování jistých cílů, vývojových stádií. Takto vyznívají též ekvivalentní výrazy: anglické "bring up" znamená odkázanost životního pohybu na podporu okolí, a také nezbytnost jistého úsilí pro překonávání sil přirozené gravitace; má na mysli "vysoké" ideály humanity. Pro jiné anglické slovo, "educe" existuje překlad s velmi moderním smyslem: rozvinout z podmínek latentní, nebo jen omezené, potenciální existence. Českému vzdělávat rozumíme nejen jako soustavné práci, ale i jejím souvislostem s celkovým a "vyšším" smyslem.

Západní vzdělávací tradice vychází z hlubokých úvah Platóna a Aristotela o lidském růstu a vývoji. "Latentní či potenciální existence" se pojí se základy Aristotelské filozofie. Dialektika potenciálního a aktuálního, formy a látky je podstatou jeho metafyziky (často zvaná "hylemorfizmus", hylé = látka, morfé = forma). V tomto celkovém přístupu je vzdělání probouzením - uskutečňováním možností skrytých v individuální lidské bytosti. Má vztah k duši, jež je složena ze dvou částí: racionální a neracionální. Lidé jsou racionálními živočichy a tento díl své duše sdílí s bohy. Nerozumná část duše odhaluje

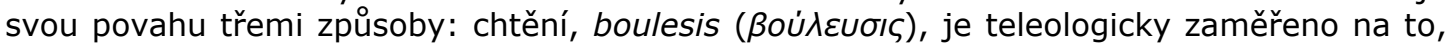
co je považováno za dobré; chut́, epithymia, na př́jemné; vášeň, thymos, je spojena se studem, ctí a zlobou. Tato duše je tedy sídlem emocí ( $n a \dot{\theta} \eta$ - dva poslední obsahy duše) a žádostí a náleží jí etické ctnosti. Obě části duše však spolupracují: potřebují totiž vzájemné přispění, aby se plně rozvinuly, tedy aby dospěly ke svým ctnostem. V Nikomachově etice pak Aristoteles vysvětluje prvotnost těla a žádostí nad duší a porozuměním. A podle toho tedy stanovuje pořadí péče - staráme-li se přednostně o tělo, je to ku prospěchu duše, pečujeme-li o žádosti, je to $v$ zájmu rozumu a porozumění. Žádosti jsou pozitivní silou, které při vhodném zacházení a péči přivádějí ke ctnostem (podle Aristotelovy definice je ctnost záměrně volícím stavem a při aktu volby spolupưsobí složky rozumné i nerozumné, totiž uvažování i žádost) (Stehura, 2006).

Současná kurikula ovšem Aristotelovu dialektiku racionálního a ne-racionálního neuznávají, a jejich zaměření $\mathrm{k}$ blahu jedince a společnosti - které je pouze racionálně založeno - je značně jednostranné.

\section{Základní etické argumenty}

Sokrates tvrdí, že přání člověka jsou konečná a člověk nemůže dosáhnout naprostého uspokojení na základě toho, co si přeje (dialog Gorgias). Platón pak nachází nedosažitelný svět idejí, kde jsou „ztělesněny" touhy i představy; máme-li schopnost nahlédnout tyto ideální podstaty, zjistíme, že smyslově vnímaná skutečnost je jejich pouhým stínem. Ideální svět poukazuje $\mathrm{k}$ opravdovosti, pravdivosti a dobru, a vše jednotlivé uskutečňuje tyto nutné vztahy. Ideje tak sice nelze prímo pozorovat, přesto dodávají světlo všemu ostatnímu. Zdrojem všech hodnot je idea dobra. Dává životu smysl a její poznání je nejvyšším cílem. Dělat, co je správné, a spravedlivě ř́dit společnost je pak otázkou poznání - a to nejen poznání jednotlivých věcí (ty jsou pouhými stíny), ale především ideje dobra. Pokud po něčem toužíme či někam směřujeme, jsme vedeni rozumem, který se zaměřuje na mimo smyslově poznatelný svět. 
Podle Nikomachovy etiky je společným a všeobecně lidským cílem a úmyslem nejvyšší blaženost (eudaimónia), jež však není totožná s uspokojením. Obecnému cíli veškerého vzdělání, jímž je výchova dobrých a št́astných jedinců, jednajících v zájmu společenské harmonie v obci - "polis" - může prospět "theoría", vhled, pohled na skutečnost, související s celkovým životním stylem ("theoría" původně znamenala vztah k bohům - theos; později jde o hluboké porozumění). Nejvyšší blaženost má smysl životního zaměření, naplnění, a lze jí dosáhnout cestou rozumu, který tak zahrnuje silný mravní aspekt. Praktický rozum spočívá v možnosti uskutečňování toho, co je rozumově považováno za dobré; myšlení pak není jen porozuměním, ale vede také ke schopnosti jednat. Etika je rozum uvedený do praxe, má bezprostřední vztah ke kvalitě života. Celková životní orientace ke štěstí není samozřejmostí, jde v ní o smysl, který je nutné stále hledat rozumným rozvažováním. Prakticky to znamená, že smysluplný život je vždy orientovaný; dobro, k němuž směřuje, není samozřejmé, vedou k němu úvahy praktického rozumu.

Samotná pravda se odhaluje ve skutečnosti nebo ideálu, ukazuje se jako to, co je v nich původně skryto, je vstupem do neskrytosti (alétheia); pravdu tak nelze mít či vlastnit, je ale možné na ní participovat, účastnit se onoho dění otevřenosti. V platonizmu nabývá ideální povahy - je věčnou, neměnnou a absolutní vlastností, metafyzickou podstatou všeho jsoucího. Stává se spolehlivým základem skutečnosti, a z této podstaty vycházejí také pozdější racionalistické koncepty. Základní rozvrh pravdy je však nadále tento: nezajištěnost východisek (stálá nutnost návratu k počátku, arché), transcendentní povaha (překročení bezprostřední skutečnosti, přesah) a závaznost důsledků (všudypř́tomná nahlédnutelnost či ověřitelnost, jež současně vyzývá k obecnému respektu a odpovědnosti).

Takto formulované ideje dobra a pravdy jsou pro člověka mnohonásobnou výzvou: nejen k poznání a nahlédnutí, ale především k soustavné péči. Svět, který může být dobrý a pravdivý (at' již tyto atributy pocházejí od Boha či nikoliv), se takovým stává přičiněním člověka, který o něj pečuje (at́ již mu to ukládá Boží zákon či ne). Lidské úsilí má smysl zlo je odchylkou od správnosti světa (at' již tato správnost je přirozená či společensky vytvářená) a jen cílevědomým úsilím Ize zjednat nápravu. Proměna světa k dobrému je v lidských silách (a to i v křestáanském pojetí). To, co by mohlo a mělo být, pak není záležitostí zbožného přání, ale rozumného nazření - v tomto světle získává i lidské poznání normativní dimenzi.

Ideální rozměr skutečnosti $v$ evropském dědictví už zůstal: udržitelný rozvoj je pokládán za regulativní ideu, určitou možnost, kterou je však třeba teprve uskutečnit.

\section{Etika v teorii}

Etika, (eqos, ethos) ve své řecké podobě označuje zvyk, chování, charakteristický způsob vedení individuálního lidského života. Počínaje Aristotelem je etika studiem lidského chování; Stoikové vyvozovali, že veškeré chování - at' už dobré nebo špatné vychází z ethos individua (Peters, 1967). Dnes se etikou rozumí vědomý soubor zásad, které platí ve společenském soužití. Z etiky pak vychází morální jednání; Binka (2005) charakterizuje vztah mezi etikou a morálkou podobně jako rozdíl mezi pravidly hry šachy a všemi odehranými partiemi této hry. Psaná či nepsaná pravidla hry určují "hřiště" a "povolené tahy" (to je etika), každá odehraná partie je pak konkrétní jednotlivou aktualizací těchto pravidel (morální jednání). Jako zvláštní nauka o hodnotách se vyčleňuje axiologie, analyzující hodnotové systémy lidských společenství.

Etika není samozřejmou součástí skutečnosti; principy, kterými bychom se měli řídit, nevyplývají ze současného stavu. Z toho, co prostě je, tak nelze vyložit ani dokázat, co má být. Takový závěr by se musel podle pozdějšího filozofa G. E. Moora (Principia Ethica, 1903) označit jako naturalisticky chybný. To, co Ize v realitě popsat, musí být totiž považováno za neutrální, a teprve úsudek založený na mravních principech (poznání ideálního dobra), mưže ukázat k žádoucímu budoucímu stavu (Thompson, 2004). 
Uskutečňování etických principů plně souvisí s lidskou svobodou, kterou neurčují důsledky přirozené nutnosti. Etické rozvažování nevychází z diktátu důvodu: popis jakkoli děsivých situací totiž není argumentem, podporující mravní postoje. Jde o budoucnost, jež nemá být výslednicí přirozených sil a procesů, ale naopak něčím, oč je třeba usilovat; ani dosažený stav nemưže být přirozeně udržován, obnovován bez soustavné péče. Takové úsilí se zakládá na určitém, v osobní rovině vedeném či potvrzeném, rozhodnutí o transcendentní, individuum přesahující podobě dobra a závazné, $k$ odpovědnosti vyzývající povaze pravdy. Jde o pravdu životní, nikoliv pouhou shodu se skutečností - její pravdivost vychází nikoli $z$ analogie se skutečností nebo podobnosti s tím, co již bylo rečeno $v$ jiných situacích, ale naopak $z$ principu účasti. Tedy také řád platnosti těchto etických kategorií má zvláštní povahu: správnost (vztah k pravdě) či přiměřenost (vztah k dobru) jsou potvrzovány nikoli ve shodě s realitou, ale na základě vnitřního prožitku odpovědnosti, přesvědčení. Pak tedy etickému rozměru skutečnosti nelze rozumět či jej přijmout pouze $z$ tradice a tedy $v$ souladu $s$ běžným míněním a zvykem, ale ani pouze na základě úvah čistě abstraktních. Je záležitostí vlastního (celkovým smyslem a pochopením orientovaného) rozhodnutí, jež je vedeno rozumnou rozvahou, a nabývá konkrétní podoby až díky situaci, ve které je třeba původní orientaci osvědčit, potvrdit její "dobrotu a pravdivost". Konkrétní správnost a přiměřenost rozhodnutí je třeba vždy znovu nacházet, dopracovávat se k nim.

Etika je také ve vzdělávacím procesu všudypř́tomná - jde přece o dosahování dobrých výsledkư a pěstování k tomu potřebných morálně-volních vlastností (jež jsou nezbytné posléze i $\mathrm{k}$ uplatnění $\mathrm{v}$ praktickém životě), a to na pozadí jistého řádu. $\mathrm{K}$ tomu jsou nezbytná jistá a závazná "pravidla hry”, která by zajistila spravedlivé ocenění výsledků takto vedeného úsilí. Jak bylo ale vyloženo výše, tím role etiky zdaleka není vyčerpána a stojí za to se jí dále zabývat. Především by měla být reflektována (to znamená, že by si ji také pedagogové uvědomili) samostatně. Ačkoli je praktickou záležitostí, neměla by být praxi, tedy osobnímu př́kladu učitele, zcela ponechána. To by totiž vyloučilo dialog, biologickou hantýrkou řečeno, učinilo z dětí otisky či klony svých vzorů, znemožnilo hledání nových řešení a obecné (evoluční) tříbení.

\section{Praktické důsledky - co je a co by mohlo či mělo být}

Je-li etika takto teoreticky vymezena, ukazují se teprve možnosti lidské svobody. Člověk může rozhodovat o podobě budoucnosti, jednat na základě těchto rozhodnutí a převzít odpovědnost za své jednání. Vzniká pak také prostor pro vznik čehosi radikálně nového: jsme schopni přijmout odpovědnost i za to, co bylo dosud neslýchané, tato schopnost však souvisí nikoli s bezmyšlenkovitým přijetím stávajících pravidel, ale spíše s odvahou vedenou vnitřním nahlédnutím pravdy a dobra.

Ve vztahu ke každodenní skutečnosti i transcendentnímu ideálu pak k nejvyšší odpovědnosti volá právě evropská tradice. Je založena na řeckém myšlení, které si od počátku kladlo otázky po tom, co je pravda a dobro, a vycházelo z přesvědčení, že skutečnost má svůj smysl a rád. Na této nelhostejnosti, snaze najít a potvrdit, co je správné, pak založilo i jednání a budovalo jeho předpoklady. Pravda $\mathrm{k}$ nim patří především: postupně nikoli jako trvalá podstata, požadavek autority nebo soubor pravdivých vět, ale cosi, k čemu je možné pouze (avšak jednoznačně) směřovat. Pravda tedy takto JE, i když nesamozřejmě - je třeba o ni stále usilovat a vše, co s ní souvisí, vystavit kritickému pohledu, $v$ praxi pak kontrole. $\mathrm{V}$ tomto procesu se vytvář́ struktura pevných pravidel, na nichž Ize trvat; současně ale nejen myšlení, ale i praktické uspořádání podléhá soustavné revizi a tak se brání dogmatismu. Trvající úsilí o základní orientaci ve světě, podle které se Ize rozhodovat a následně jednat, toto soustavné hledání a budování záchytných bodů, se pak stává předmětem každodenní péče.

Za druhé a možná především je tato naše (evropská) tradice nejen pouhým přesvědčením, že o pravdu je možno a nutno se zasadit, dobývat ji myšlenkovým úsilím, 
a soustavně o ni pečovat, systematicky ji zajistit. Byt' dočasně vydobytá, ale ( $v$ tu historickou chvíli) platná pravda musí být uskutečněna a bráněna. $\mathrm{K}$ tomu si západní svět buduje systém práva a institucí, jež sice podléhá soustavné kontrole a proměně $v$ rámci demokratického dialogu, současně ale je v konkrétní podobě platný. Občan se mu ve svých životních situacích stále zodpovídá - nemůže tak společensky existovat jinak, než v plné odpovědnosti. Pokud se změní představa o tom, co je pravdivé a tedy závazné, je třeba to dokázat - a jestliže se tak stane, musí se také proměnit náš institucionálně a právně založený svět. Každé (filozoficky i prakticky podložené a vedené) úsilí o přetváření etických rámců má potom logický důsledek ve vzniku nových pravidel a mechanismů jejich zajištění

Podobné úvahy vedou $\mathrm{k}$ následujícím závěrům $\mathrm{v}$ oblasti praxe: možnost a nezbytnost odpovědně rozhodovat o podobě budoucnosti (tedy ve vertikální dimenzi lidského usilování), je "materializována", vyjádřena institucionálními a právními nástroji, které regulují přirozené zájmy a postoje ve prospěch sdíleného ideálu spravedlnosti. Souvislost fungování práva a institucí $s$ přijatými etickými normami poskytuje společenským mechanismům hlubší základ (nemají zajištovat pouhé účelné fungování společnosti) a podporuje jejich flexibilní povahu; takto připuštěné možnosti změn jsou potom konkrétní společností rozvíjeny dle jejích (demokratických či jiných) zásad. Př́kladem je ekologické zákonodárství, jež vznikalo v historicky dohlédnutelné době (u nás od 90. let minulého století) a vneslo do společenských procedur a funkcí četné změny (např́iklad posílilo zásadní úlohu nevládních organizací v této oblasti). Legislativa se stále dynamicky vyvíjí, uznává se, že jednou z nejdynamičtějších oblastí v mezinárodním právu bude hledisko životního prostředí. Tak právo naší doby odpovídá na nesmírně zničující sílu, kterou jsme se teprve relativně nedávno vnímat naučili (Purdon, 2001).

Na druhé straně, i v horizontální dimenzi každodenního vztahu ke skutečnosti, má etické uvažování svou důležitou úlohu. Je formováno Aristotelskou představou přirozeného řádu přírody, v němž každá živá bytost dosahuje své dokonalosti, "arété", přirozeně. I samotná příroda je souhrou přirozených pohybů a podléhá přirozenému zákonu; svět je tedy uspořádán dobře, protože je možno se orientovat s dưvěrou ke spolehlivému řádu kosmu (takto se projevuje římsko-stoická důvěra $v$ dobrotu nutnosti). $\mathrm{V}$ křestáanském pojetí se stává přirozený řád mimolidského světa také morálním řádem svobodného lidstva. Ke světu je třeba přistupovat z tohoto východiska a směřovat k nalezení vhodného a především harmonického vztahu či postavení člověka v rámci daného řádu - jinak bude lidské konání zhoubné. Ekologické myšlení tato východiska radikalizuje: pokládá často člověka za násilného vetřelce, který přírodu zasahuje a ničí; v rámci přijaté odpovědnosti pak klade požadavek návratu do původního řádu přírody či alespoň uvědomělého formování individuálního životního stylu (Kohák, 1998). Praktickým důsledkem jsou především pokusy o zásadní změnu spotřebitelského chování.

Ve vertikální, spirituální dimenzi lidského života (ve vztahu k jeho celkovému smyslu, vzhledem k ideálním představám o dobru a pravdě, jež život pưvodně orientují), ale i v dimenzi horizontální, v každodenních okolnostech praktického usilování, jsou etické možnosti otevírány teprve znovunalezením vztahu Já - Ty, překonávajícím abstraktní vztah Já - Ono novověkého subjektivismu (Drozenová, 2005). Jinak by se také samotná etika redukovala na pouhý soubor pravidel slušného chování a představovala by jen jakousi etiketu - nezbytnou pro socializaci jedince, avšak těžko pochopitelnou, zvnitřněnou. Pokud by se naopak upnula k formulaci dlouhodobých a jaksi "vyšších" cílü, aniž by trvala na činné účasti a žitém vztahu k této abstraktní skutečnosti, směřovala by k jisté formě revoluční ideologie. Vztahy $\mathrm{k}$ bezprostřední skutečnosti i k tomu, co považujeme za východisko, smysl či cíl svého usilování, je tedy třeba soustavně kultivovat.

${ }^{6}$ Tak v oblasti lidských práv dochází k vývoji. Zejména mezinárodní právo se proměňuje směrem $\mathrm{k}$ samostatnému lidskému právu na životní prostředí - viz níže. (Purdon, 2001) 
V rovině individuální i společenské praxe pak záleží na hledání a vždy novém ustavování rovnováhy mezi každodenní péči na straně jedné, a starostí o transcendentní ideál na straně druhé (dimenze horizontální i vertikální). Jde tedy o to, uskutečňovat proměnu sebe i okolního světa současně - nelze totiž předvídat důsledky pouze jedné z těchto proměn. Otázku, co by se stalo, kdybychom náhle byli všichni skromní, řešila Hana Librová hypoteticky ve Vlažných a váhavých. Po konzultacích s profesorem ekonomie Lubomírem Mlčochem pak došla k závěru, že by nastal kolaps - nejen ekonomický, ale i sociální (Hledám důstojný životní styl, 2003). Pouhé naplnění hesla "já v tom nejedu" a odpovědné chování ve vlastním mikrosvětě by tak ještě nevedlo k zásadnímu zlepšení stavu životního prostředí. Šlo by o pouhou destrukci současných ekonomických vazeb (byt' v rovině individuální, zdánlivě neškodné), nikoli rekonstrukci prostředí, které nám nechtě vnucuje svá pravidla - poskytuje základní podmínky přežití, které přece není jen záležitostí biologickou. A tak v současné situaci je zapotřebí nejvíce právě odpovědné rekonstrukce, která také vyžaduje větší míru informovaného rozhodování, vưli ke změně a schopnost si přčítat její důsledky.

Tyto závěry jistě mohou poskytnout plodnou inspiraci praxi a jsou relevantní i pro samotnou oblast vzdělávací. Jak již bylo řečeno, v úvahách o tom, co by mělo být, nepomůže poukaz na jakkoli zdůvodněnou nutnost, ani dokonalé informační prostředí (Pinc, 2006). Při hledání cest a řešení příznivých pro životní prostředí se na pouhé znalosti spoléhat nelze: i kdybychom totiž věděli o světě všechno, co je vědění vůbec dostupné, nepomůže to $v$ hodnocení, co je pro budoucnost dobré a co špatné. V takovém rozhodnutí neporadí ani zákony - ty pouze vymezují okruh našich možností a ve své podstatě naopak z etických argumentů, z představ o dobru a spravedlnosti, vychází.

Z těchto úvah je patrné, že etický diskurs není samozřejmě zahrnut v obvyklém poznávacím procesu; samotná etika je odlišná od faktů, jimiž popisujeme skutečnost (i kdybychom těmto faktům přiřadili hodnocení). Schopnost užívat praktického rozumu je tak třeba rozvíjet samostatně, a to soustavným kladením a rozvažováním etických argumentů v konkrétních životních situacích. Myšlení, jež je takto utvářeno, se vyznačuje príčctností (přičítáním si důsledků svých činů) a odpovědností; vychází z principu rozumné péče o každodenní skutečnost a pěstuje vůli $\mathrm{k}$ dobru a pravdě, jež součástí této bezprostřední skutečnosti naopak nejsou, Ize $k$ nim však směřovat $v$ sebepřekročení (transcendenci) vlastních a okamžitých zájmů. Jakkoli jsou pak tyto pojmy a závěry $v$ teoretické rovině relativizovány, znamená to právě jen nutnost oddělení této teorie od etického diskursu, jejich samostatné rozvíjení. Pro oblast životní praxe, jíž rozumíme účinné a smysluplné vedení lidského života, jsou totiž úvahy etického rázu nepostradatelné.

Své rozhodování ohledně toho, co má být nakonec nemůžeme svěřit ani sebelepším modelựm a dlouhodobým předpovědím - vždy zưstane na nás. Malá ochota zabývat se budoucností je pak hlavním nedostatkem současného vzdělání, jak naznačují např́klad autoři Teaching and Training for Sustainable Future, vzdělávacího programu UNESCO, který mapuje světové vzdělávací trendy a o jistou univerzální platnost také usiluje (UNESCO, 2002).

\section{Ekologická etika}

Jak bylo vyloženo, katastrofické zprávy o špatném stavu životního prostředí mohou být jen roznětkou malicherných či globálních soubojů o poslední zbytky zdrojů a požitků, jež příroda nabízí. Rozhodnutí (na všech úrovních), pouze diktovaná vážnými důvody a plně spoléhající na komplexní informace, z nichž Ize př́mo odvodit spolehlivé předpovědi a tedy i varianty možného vývoje, nezakládají odpovědné jednání, nestvrzují (po staletí dobývanou a užívanou, avšak příčetnou, tedy důsledky svých činư si přičítající) svobodu lidského rodu a vedou spíše do světa nové př́rodní nutnosti. Normy, které by těžily z nevyhnutelné potřeby či objektivní krize, zakládaly by se na tomto dưvodu a směřovaly 
k nápravě světa změnou pravidel i hodnotových řebříčků, se ocitají na pomezí neživotné etikety či nebezpečně směřují k revoluční ideologii.

Diskuze o tom, jak založit soubor pravidel pro vztah s mimolidským světem, především živočichy, ale i prostředím jako takovým, jde často ruku $v$ ruce $s$ úvahami o původu ekologické krize - její kořeny se hledají v základech evropské kultury. Tradiční schéma novověkého myšlení staví př́rodu jakožto projevenou původní přirozenost do kontradikce proti člověku, který na svou přírodní podstatu navršil civilizační změny. Takové úvahy potom nutně vedou $\mathrm{k}$ otázce: kde se stala chyba, kdy se člověk svému pravému základu zproneveřili? Většina směrů environmentální etiky chce tak či onak obejít křižovatku, na které se lidé vydali špatným směrem; nejradikálnější autoři vidí chybu vůbec $v$ lidské podstatě a jiní se nechávají inspirovat životním stylem př́rodních národů (Činčera, 2001). V souboji o nový "ekologický diskurs" vznikají nové směry etického myšlení (Kohák, 1998).

Následující přehled ale ukazuje, že mnohé oblasti ekologické etiky, jejichž cílem je položit nové základy lidského společenství, vůbec neotevírají možnosti úvah praktického rozumu, které by se týkaly konkrétní podoby dobra, pravdy, spravedlivého uspořádání, a byly by vedeny i potvrzeny životní zkušeností, vnitřním prožitkem. Ekologie, věda o zákonitém a nutném chování $v$ rámci nepřekročitelných možností př́rody, se $\mathrm{v}$ nich naopak stává protikladem etiky, nároku svobodného morálního činu a jednání. Ekologické etice v dobrém slova smyslu jsou nejblíže teologické př́stupy, které se zamýšlejí nejen nad osudy prírodního prostředí, ale především nad posláním člověka, který „měl být od počátku podle Božího rozhodnutí pastýřem stvoření a měl rázem svého jednání, svého ,pasení, tomuto jinak neoslovitelnému stvoření dosvědčovat Boží lásku." (Heller, 1994/95) Zdá se, že také zde, ve vztahu $\mathrm{k}$ zákonitě fungující přírodě, se etika neobejde bez něčeho tak neuchopitelného jako je láska.

\section{Etika úcty $k$ životu}

Biocentrismus vychází z představy, že život sám, život jako takový, všechen život, je zdrojem smyslu a hodnoty. Prožitek hodnoty života je ve svých kořenech náboženský $\checkmark$ prvotním vnímání světa jako posvátného, naprosto ne-samozřejmého. Úcta $k$ životu počíná prožitkem údivu nad životem. $V$ tomto pohledu by hodnotový systém, který by se zabýval jen vztahy mezi lidmi, byl neúplný a tak by postrádal sílu dobroty - jen úctou k životu Ize ustavit humánní vztah ke všem živým tvorům na dosah (Schweitzer, 1974). Každé živé stvoření má hodnotu o sobě jen proto, že chce žít, protože se dovede radovat a hrozí se utrpení a zániku; život každé bytosti je dobrem jen pro ni samou, a tedy dobrem zcela nezávisle na čemkoliv jiném. Takové dobro o sobě si zasluhuje úctu. Mezi biocentrická přesvědčení patř́:

- ne-lidé (živočichové) jsou rovnoprávnými členy společenství lidských bytostí;

- Země je soustava vzájemných závislostí;

- každý člen biotického společenství má hodnotu prostě svým bytím, jen proto, že je;

- představa o lidské nadřazenosti je výrazem rasizmu.

\section{Naturalistická etika}

je pak založená na přesvědčení, že zlo pochází z odcizení člověka přírodě, z odklonu od přirozenosti. Náboženské i naturalistické pojetí se tu z odlišných důvodů dopracovává k stejnému pojetí: príroda má svůj řád, který představuje optimální řešení sporů.

Představa o návratu (a tím o etice, o tom, co nás povede zpět do napojení s bytím) ovšem závisí na představě, jak a v čem jsme se odcizili. 


\section{Etika vznešeného lidství}

Antropocentrismus neznamená řídit se (přirozenými) lidskými zájmy, nýbrž podřídit naše jednání výrazně lidským - a to znamená morálním - kategoriím, mezi něž patří i schopnost jednat pro dobro přírody. Je třeba změnit nejen lidi, ale i pravidla jejich soužití, vytvořit novou civilizační strukturu. Od lidí je vyžadována dobrovolná skromnost, která je spíše výběrovou náročností, radostí ze života místo radosti z majetku. Ve společnosti je třeba odměňovat to, co vede $k$ dlouhodobé udržitelnosti života a jeho předpokladů a zabraňovat tomu, co udržitelnost ničí. Člověkem vstupuje do všehomíra rozměr altruismu, který je pro člověka závazný - přijetí dlouhodobého zájmu všeho lidstva za vlastní zájem se stává nezbytností. Nejde pouze o vlastní dobro, dobro individuálního člověka - jde už o dobro všeho života. Do středu hodnoty a smyslu vstupuje místo vlastního či jen lidského života život sám. Takový postoj pak mění antropocentrismus $v$ biocentrismus.

\section{Etický kodex - deontologický přístup}

Extrémní, ortodoxní směry antropocentrismu, hledají $v$ etické oblasti jistoty závazných pravidel. Deontologie se zabývá tím, co je mravní povinností člověka. Pojem je odvozen z řeckých slov deon, což znamená "povinnost; to, co se musí vykonat" a logos, což znamená "učení, věda". O zmírnění nedostatků extremní deontologie se pokouší kazuistická etika, která aplikuje morální normy na konkrétní případ (kauzus) a dává konkrétní směrnice $v$ případech kolize povinnosti. Snaží se o určení priorit při takové kolizi; a ve svých důsledcích je relativizováním přikázaného. Kauzistická etika vytváři pevné všeobecné normy pro každou situaci.

Pokud však chceme vycházet z toho, co je účelné vykonat, nelze vždy splnit to, co je všeobecně mravně přikázané. "Účel" ve smyslu řeckého pojmu telos vede k úvahám o tom, co je eticky účelné; z nich pak vzniká teleologie jakožto etika dobra. S deontologií, etikou povinnosti, se teleologie ovšem vylučuje (Kiss, 1998).

\section{Teologická reflexe environmentální problematiky}

Postoj pokory, ekologické odpovědnosti i spravedlnosti pro všechno stvoření - to jsou znaky teocentrické etiky. Jde v ní o zážitek naprosté závislosti a nekonečné moci, nerozlišuje mezi Bohem a př́rodou. Vnímá jen jedno posvátno. Člověk tu není středem všeho smyslu a zdrojem vší hodnoty, tím je posvátná příroda. Lidé jsou součástí celku, který má vlastní pravidla a vyžaduje si úctu; úkolem člověka je žít v souladu s rádem a rytmem prírody. (Skolimowski, 1985).

V křestáanství je ale také na druhé straně hledán podíl viny člověka na masovém poškozování přírody, které je vykládáno eschatologicky. V článku "Historické kořeny současné ekologické krize" (White, 1967) byla poprvé vyslovena teze, ve které je ze současné ekologické krize obviněna západní forma křestanství. Dnes je tento text považován za klasický příspěvek k danému tématu, který následně podnítil rozsáhlou debatu. Lynn White vyvozuje, že kořeny naší ekologické krize jsou z velké části v náboženství a předkládá tezi o ,podmanění země", jejíž pưvod je ve slovech knihy Genesis. Podle jeho výkladu má celé stvoření jednoznačně sloužit pouze k lidským účelům. Je to pojetí, které Ipí na doslovném znění, na liteře, a nebere ohled na záměr čili intenci biblického svědectví. White dále vyvozuje, že křestáanství je duchovním podhoubím veškeré moderní vědy, a tedy křestáanská teologie je vinna i v tomto ohledu. Tyto „,Whiteovy teze" se staly nesmírně populární a byly pak často opakovány a kritizovány. Pronikly do textů dějin techniky, společenských věd, sociologie a samozřejmě ekologie.

Katolickým stanoviskem k tomuto problému je encyklika Jana Pavla II. Centesimus Annus (1991): „Neuvážlivé ničení přirozeného životního prostředí se zakládá na dnes bohužel značně rozšíreném antropologickém omylu - člověk míní, že může svévolně disponovat zemí..." Slovu ,podmanění" je třeba rozumět v pozitivním smyslu - člověk je sice ",korunou" všeho stvoření, ale to pro něj znamená nejen zvláštní práva, ale 
i povinnosti. Ze stvoření př́rody nezávisle na člověku se vyvozuje "samostatná, od člověka neodvozená hodnota" př́rody. Důraz je třeba položit na odpovědnost člověka za planetu Zemi - at' k převzetí odpovědnosti došlo jakkoliv (Moldan, 1994).

Ekumenickou cestu ukazují také J. A. Komenský nebo A. Schweitzer. František z Assisi chápal životní prostředí jako prostředí člověka a patř́cí člověku, $v$ němž se odehrává dílo spásy a který se na tomto díle spásy zúčastňuje podle své přirozenosti - ne díky nějaké vnitřní nevyhnutelnosti, ale podivuhodné milosti Boží. Tím byl položen pevný základ úcty vưči veškerému stvoření (člověka nevyjímajíc, spíše naopak) (Brázda, 1998). (2005).

Podrobný výklad křestáanského postoje vůči všemu stvoření podává W. Drozenová

\section{Zmatek různorodosti?}

Co tedy Ize, ve světle rozporu mezi na jedné straně přírodním, vědecky založeným diskursem, a tedy také ekologickým uvažováním, a na druhé straně oblastí odpovědné svobody, etického jednání, vůbec činit? Je eschatologicky laděné moralizování jenom př́ležitostí k obhajobě fundamentalistických pozic, nárokuje návrat k nejlepším, zdánlivě však již mrtvým tradicím, nebo otevírá možnost vzniku nových paradigmat lidského soužití?

Začněme biocentrismem, který vychází z vědomí toho, že selhává náš vztah ke skutečnosti: je třeba znovu hledat místo $v$ řádu bytí. Jeho výzvou je obnova poměru $\mathrm{k}$ životu jako takovému. Odsud, $\mathrm{z}$ inspirace bytostným souzněním $\mathrm{s}$ prírodou, mohou pramenit hodnotové posuny: člověk se cítí součástí prírodního světa a přijímá jej jako rovnocenného partnera. Na tomto filozofickém základě Ize postavit teorie přirozeného zdraví a obnovy života; vést úvahy či vědecká pozorování týkající se zachování biodiverzity či humánní medicíny, tzv. antroposofie. Biocentrický postoj leží v základu prožitku přírody jako původního domova: toto je východisko pro člověka jako bytost tělesnou, domov Země poskytuje vlídné prostředí jeho životním pochodům, metabolismu, ale i estetickým prožitkům. $V$ průběhu stálých proměn a toků hmoty či energie je možno pocítit vzájemný vztah a provázanost všeho živého. Zpřítomnění vztahu $k$ prírodě, její pochopení v rádu JáTy, pak $v$ mnoha ohledech vede $k$ identifikaci problémů, jež by $v$ rutinním (myšlenkovém i praktickém) nakládání s př́rodními skutečnostmi zůstaly skryty - neměly by ani možnost se ukázat v objektivní, disponovatelné podobě věcí a jevů.

Biocentrismus je oddaným a milujícím dětstvím a poutem, u kterého - jakkoli určuje myšlení $v$ odpovědné dospělosti - nelze zůstat. Jeho logickým a racionálním důsledkem je pak vědomí, že je třeba nově založit a nést spoluúčast na světě. Prožitek vnitřní hodnoty př́rody přináší do vztahu k ní nový princip péče (Noddings, 2002, 2003): člověk se stává správcem a pastýřem stvoření, uvědomuje si svou odpovědnost za mimolidské bytosti a prostředí jako takové. Takto se zakládá etický postoj, který je rozvíjen soustavným promýšlením a užíváním principů praktického rozumu; podporuje jej kladení otázek po smyslu, hledání dobrých cílů a řešení; jeho důsledkem je vưle $\mathrm{k}$ odpovědnému jednání. Reflexe etických argumentů vede $\mathrm{k}$ vědomému rozhodování; pro následné jednání, aplikaci rozhodnutí v dané historické situaci, jako nástroj slouží právo, instituce, a také technické prostředky. Environmentalismus ${ }^{7}$ jako čistě praktická oblast ekologicky př́iznivých úprav

\footnotetext{
7 Termínem „environmentalismus" navrhuji označovat mechanistický, instrumentální názor, který považuje přírodu za pasivní habitat "objektů" jako jsou živočichové, rostliny, nerosty apod., které musí být pouze $\mathrm{k}$ dispozici $\mathrm{k}$ praktickému využití člověkem. Environmentalismus má tendenci redukovat přírodu na skladiště "přírodních zdrojü" a "nerostných materiálů"... Environmentalismus má tendenci usilovat o takový harmonický vztah mezi lidstvem a přírodou, který bude spíše príměřím, než trvalou rovnováhou." BOOKCHIN, Murray. (1982) The Ecology of Freedom. The Emergence and Dissolution of Hierarchy, Palo Alto, pp 22 Citát pochází z textu: NOVÁK, A. (2006). Zelení proti
} 
společenského i technického prostředí z často implicitních etických imperativů vychází. Sám o sobě by environmentalismus měl potíže $s$ definováním cílů (dobro chápe mechanicky, jako neexistenci zla, např. nedostatku). Environmentalisticky orientované úsilí je většinou zaměřeno na evidentní přínos (okamžité či dokonce dlouhodobější dobro), což je legitimní součástí tohoto diskursu; pokud by se však bezprostřední jasnost a bezrozpornost přenesla i do oblasti názoru (etiky či filozofie), vzniká živná půda ideologií všeho druhu.

To však platí pro každou ze součástí environmentálního myšlení, pokud se klade důraz na aplikaci a zanedbávají se širší souvislosti - at' již se staví na dětské oddanosti prakticky požadující návrat k pưvodnímu ráji, v němž člověk (ekologicky) nehřeší, pouhém filozofickém rozboru situace a stanovení norem, anebo technicky založené činnosti bez reflexe cílů a prostředků.

\section{Závěr}

Zopakovali jsme, co je etika: praktické principy účasti na životě. Jejich podoba není neměnná, vždy však jde v podstatě o dobro a pravdu, které jsou existenciálně zažívány jako základní životní orientace a smysl, resp. závazný a odpovědný vztah ke světu. Na dobru i pravdě Ize stavět praktické jednání; obojí je pro člověka bytostným a tedy žitým vztahem ke skutečnosti, která je pak v tomto vztahu utvářena, formována (samozřejmě i vice versa). Je ovšem možný i život nezúčastněný, prostá existence bez jakékoli ambice podílet se na utváření skutečnosti - vztah k dobru i pravdě je tak nesamozřejmý, neexistující přirozeně ve skutečnosti samé a musí být veden a propracováván praktickým rozumem.

Tato dvojí povaha etiky - bytostného vztahu a rozumné rozvahy - znamená i dvojí způsob založení etického postoje, morálky, i jejich dalšího rozvíjení. Prvním z principů je vztah, který - jak ukazuje Martin Buber - nemá být zakotven v řádu Já-Ono (nebot́ tam již není vztahem, svět rozvržený jako Já-Ono směřuje k využití své zásadní ne-vztahovosti ve prospěch Já), ale ve světě Já-Ty. Tento vztah předpokládá uvolnění člověka ze světa Já-Ono (Buber, 1969). V rovině každodennosti je Ono popíráno ne-vlastněním věcí a přivádí $\mathrm{k}$ dobrovolné chudobě a skromnosti; $v$ rozvrhu řeči pak toto Ty může být pojmenováno jedině metaforicky. Vzdálenost, která nese polaritu vztahovosti, je třeba překlenout dialogem - a tedy rozumem vztah pokaždé znovu nacházet.

Podoby dobra a pravdy nejsou absolutní a trvalé, ale ani „historicky relativní" (a tedy stejně strnulé, jen $v$ určitých mezích proměnlivé, závislé na okolnostech). Objevují se teprve v konkrétní lidské situaci a prostřednictvím činné účasti na ní.

Byly rozebrány praktické důsledky těchto (pouze) teoretických úvah pro ekologickou etiku - je tak vidět, že neznalost existujících myšlenkových zdrojů vede k naivním závěrům o podobě "vhodného či závazného souboru norem chování" (ekologické etiketě) či cestě $\mathrm{k}$ „proměnám paradigmat a podob společnosti" (revoluční ideologie). To je zvláště patrné ve vzájemném odtržení obou dimenzí lidské situace: horizontálního vztahu ke světu s jeho každodenní potřebou pravidel a na druhé straně vertikální cesty za ideálem, projevující se aktivním snažením o spoluúčast na utváření světa.

Tradice evropské kultury poskytuje základ pro odpovědný vztah k přírodě, navíc také pro soustavnou péči o tento vztah a jeho praktické rozvíjení $v$ rovině legislativní, institucionální a jiné. Často, pokud jsou myšlenkové a etické koncepty naší společné

zeleným. Radikální ekologie - komparativní analýza sociální ekologie a ekologie hlubinné. Magisterská práce. Praha: KSKE, FHS UK. In: Envigogika 1/2006. COŽP UK. ISSN: 1802-3061 
minulosti kritizovány, jde o vytržení dílčích přistupů ze souvislostí doby či kontextu, ve kterém byly formulovány. Jejich povrchní a neinformované vyjádření v postmoderním prostředí se míjí s původním smyslem a vede $\mathrm{k}$ deziluzi, která se týká nejen základů naší civilizace, ale $i$ možností aktivního a $v$ dnešní situaci $i$ zcela nezbytného zásahu do "mechanického" běhu světa.

\section{Literatura}

- $\quad$ Aristoteles, (1996). Etika Níkomachova. přel. Antonín Kř́ž. Praha: Rezek.

- Binka, B. . Ekologická etika 2 - reflexe ekologické krize. Materiál ke kurzu, Katedra podnikového hospodářství. : Katedra podnikového hospodářství, Ekonomicko-správní fakulta MU. Retrieved from http://www.econ.muni.cz/katedry/KPH/stud/etika/e3.doc

- Brázda, C. J. (1998). František z Assisi - patron ekológov a ochrancov prírody. Životné prostredie. Životné prostredie, 32(2),

- $\quad$ Buber, M. (1969). Já a Ty. Praha: Váhy.

- Časopis Životné prostredie (2002). Hodnoty udržatel'nosti života. Časopis Životné prostredie, 5

- Časopis Životné prostredie (1998). Náboženstvo a životne prostredie. Časopis Životné prostredie, 2

- Časopis Životné prostredie (1999). Starostlivost' o životné prostredie. Časopis Životné prostredie, 6

- Činčera, J. (2006). Trendy v environmentální výchově - intepretivistický a kritický proud. Envigogika, 1, Retrieved from http://envigogika.cuni.cz

- Činčera, J. (2001). Environmentální informační systémy a humanistická environmentalistika texty k výuce. : Vyšší odborná škola informačních služeb v Praze.

- Delors, J. (1997). Učení je skryté bohatství (formulovala Mezinárodní komise UNESCO Vzdělávání pro 21. století). Praha: UIV.

- Dorotíková, S. (1998). Filozofie hodnot. Praha: Pedagogická fakulta UK.

- Drozenová, W. (2005). Země je plna tvých tvorů. Tři studie o vztahu křest’anství k př́rodě. Praha: Karolinum.

- Ehrlich, A., \& P, (1987). Earth. London: Thames-Methuen.

- Fien, J. (2004) Education for the environment: critical theorising and environmental education. In S. Gough \& W. Scott (Eds.), Key Issues in Sustainable Development and Learning: A Critical Review (pp. 93-99). London/New York: RoutledgeFalmer.

- Heller, J. (1994). Člověk - pastýř stvoření. Universum, Revue přírodovědecké a technické sekce České křest’anské akademie, 16 (1994/95),

- Sedmá generace, 12/2003 Téma: Skromnost jako životní styl. Hledám důstojný životní styl (Martin Ander a Dagmar Smolíková: rozhovor s Hanou Librovou). Sedmá generace, 12/2003 Téma: Skromnost jako životní styl, Retrieved from http://www.sedmagenerace.cz/index.php?art=show\& cislo=12\&rocnik=2003

- Hrehová, H. . Nová etika hodnôt alebo humanistická vízia jednotnej Európy. . Retrieved from http://pdf.truni.sk/s/kpsychet/zborn2.pdf

- Keulartz, J. (1998). Struggle for Nature. A Critique of Radical Ecology. London/New York: Routledge. 
- Kohák, E. (1998). Zelená svatozář (Kapitoly z ekologické etiky). Praha: Sociologické nakladatelství (Slon).

- Kohák, E. (1993). Člověk, dobro a zlo: O smyslu života v zrcadle dějin: kapitoly z dějin morální filosofie. Praha: Ježek.

- Komenský, J. A. (1948). Vševýchova Panpaedia. Praha: Státní nakladatelství v Praze.

- Mezrìcký, V. (ed.), (2003) Globalizace. In . Praha: Portál.

- Mezřický, V. (2002). Názory některých křest’anských myslitelů na ekologickou krizi hodnot a odpovědnost křestanů. Život. Prostr., 36(5),

- Moldan, B. (1994). . Křest'anská revue č. 8/1994,

- Nečas, J. (2004). Ekogramotnost. Getsemany, 146(1/14), Retrieved from http://www.getsemany.cz/node/617

- Lyotard, J. F. (1993). O postmodernismu. Postmoderno vysvětlované dětem. Postmoderní situace. Praha: Filosofický ústav AV ČR.

- Kiss, I. (1998). Deontologia alebo teologia v etike?. Životné prostredie, 32(2),

- Noddings, N. (2002). Educating moral people: A caring alternative to character education. New York: Teachers College Press.

- Noddings, N. (2003). Caring: A feminine approach to ethics \& moral education. : Berkeley: University of California Press.

- $\quad$ Peters, F. E. (1967). Greek Philosophical Terms: A Historical Lexicon. New York: NYU.

- Petříček, M. (1997). Úvod do současné filosofie. Praha: Hermann \& synové.

- Pinc, Z. (2006). Instinkty, pouta, informace. Křest'anská revue - Myšlení v informačním věku, LXXIII(6/2006),

- JÄmsa, T. (2006). ducation and Sustainable Development: First Steps Toward Changes Volume 1. Daugavpils: Baltic and Black Sea Circle Consortium.

- Platón, (2000). . Praha: OIKOYMENH.

- Pratarelli, M. (2003). Why Big Brains Consumed an Ecosystem. Colorado: Medici Publishing.

- Purdon, C. (2001). Lidská práva a životní prostředí: Na křižovatce.. : Univerzita McGill (kandidátka LL.B./B.C.L).

- Skolimowski, H. (1981). Eco-Philosophy: Designing New Tactics for Living. Boston, Mass: Marion Boyars.

- Stehura, E. (2006). Jednání a rozhodovací proces v Aristotelově Etice Nikomachově. Diplomová práce. : UP Olomouc.

- QCA, Qualification and Curriculum Authority . : National Curriculum Online. Retrieved from http://www.nc.uk.net/nc resources/html/valuesAimsPurposes.shtml

- Sedmá generace . Skromnost jako životní styl. Sedmá generace, 12/2003, Retrieved from http://www.sedmagenerace.cz/index.php?art=show\&cislo=12\&rocnik=2003

- Thompson, M. (2004). Přehled etiky. Praha: Portál.

- Uhliŕr, M. Věda a globalizace. In Dlouhá, J., Dlouhý, J., Mezřický, V. (Ed.), Globalizace a globální problémy. Sborník textů k celouniverzitnímu kurzu 2005 - 2007 (pp. 207-220). : Univerzita Karlova v Praze, COŽP. 
- UNDP, UNEP, World Bank and WRI, (2000). World Resources 2000-01. New York: Oxford University Press.

- Unesco, (2002). Teaching and Learning for a Sustainable Future. A Multimedia Teacher Education Programme. .

- VÚp, (2006). RVP ZV. . Retrieved from http://www.vuppraha.cz/download.php?f=priloharvp zv.pdf

- Welsch, W. (1993). Postmoderna. Pluralita jako etická a politická hodnota. Praha: KLP. 
Časopis Envigogika vydává Centrum pro otázky životního prostředí UK. Vývoj časopisu je podpořen projektem OP VK Mezioborová sít udržitelného rozvoje.

Více najdete na internetových stránkách projektu mosur.czp.cuni.cz
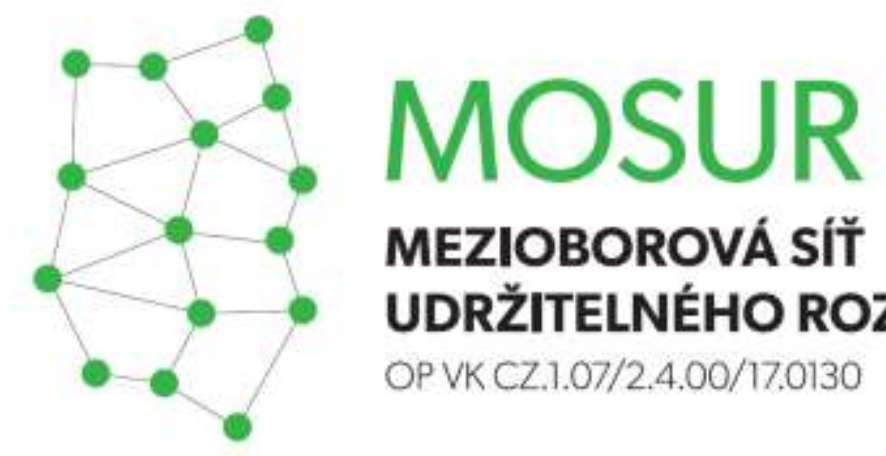

\section{MEZIOBOROVÁ SÍT} UDRŽITELNÉHO ROZVOJE

OP VK CZ.1.07/2.4.00/17.0130
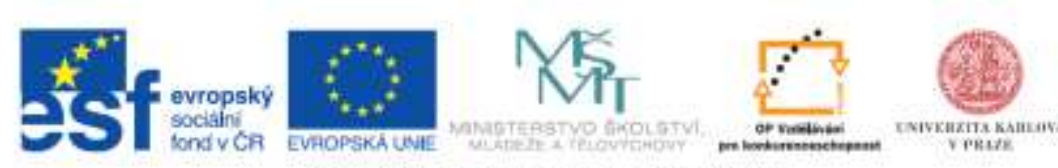

INVESTICE DO ROZVOUE VZDELAVANI 